\title{
Particle retention efficiency of asari clam Ruditapes philippinarum larvae
}

\author{
Naoaki Tezuka ${ }^{1, *}$, Erika Ichisaki ${ }^{2,3}$, Masaei Kanematsu ${ }^{1}$, Hironori Usuki ${ }^{1}$, \\ Masami Hamaguchi ${ }^{1}$, Kazuo Iseki ${ }^{2}$
}

\author{
${ }^{1}$ National Research Institute of Fisheries and Environment of Inland Sea, Fisheries Research Agency, Maruishi 2-17-5, \\ Hatsukaichi, Hiroshima 739-0452, Japan \\ ${ }^{2}$ Hiroshima University, Kagamiyama 1-4-4, Higashi-hiroshima, Hiroshima 739-8528, Japan \\ ${ }^{3}$ Present address: Nagasaki Prefectural Institute of Fisheries, Taira 1551-4, Nagasaki 851-2213, Japan
}

\begin{abstract}
Larval food abundance is one potential cause of recruitment variation in benthic invertebrates, including bivalves. Bivalve veliger larvae can clear particles $<\sim 10 \mu \mathrm{m}$. However, the particle retention efficiency (PRE) of bivalve larvae differs among species, so is necessary to determine larval food abundance in nature. We investigated the PRE of larvae of the asari clam Ruditapes philippinarum, which recently has greatly decreased in numbers in Japan. Artificially hatched larvae from the umbo to the full grown stage were exposed to natural food assemblages. Larval clearance rates were determined for particles in 32 size ranges from 0.8 to $18 \mu \mathrm{m}$. We observed significant clearance of particles in the $\sim 1$ to $8 \mu \mathrm{m}$ size range, with the highest clearance rates being on 1.4 to $2.0 \mu \mathrm{m}$ particles. Larval ingestion of the natural food assemblages ranged from $50 \times 10^{2}$ to $120 \times 10^{2}{\mu \mathrm{m}^{3}}^{3}$ ind. ${ }^{-1} \mathrm{~h}^{-1}$, which is below the hatchery food ration, suggesting larval food limitation in nature.
\end{abstract}

KEY WORDS: Ruditapes philippinarum $\cdot$ Clam larvae $\cdot$ Clearance rate $\cdot$ Particle retention efficiency Resale or republication not permitted without written consent of the publisher

\section{INTRODUCTION}

Events affecting larvae greatly influence the population dynamics of benthic marine invertebrates with planktonic larvae, including bivalves found in soft sediments (Thorson 1950, Ólafsson et al. 1994). Variation in larval food abundance is one potential cause of recruitment variation because it influences larval growth and survival (Liang 1995, Chícharo \& Chícharo 2001, García-Esquivel et al. 2001, Bricelj \& MacQuarrie 2007, Przeslawski et al. 2008). However, it is difficult to evaluate larval food abundance in nature because information on larval diet is limited (Bos et al. 2006).

The natural diet of bivalve veliger larvae is thought to be nanoplankton (Baldwin 1995, Raby et al. 1997, Sommer et al. 2000). In laboratory experiments with Mytilus edulis larvae, the highest clearance rate was seen for food particles in the size range of 2.5 to $3.5 \mu \mathrm{m}$ (Riisgård 1980, Sprung 1984a). Particle retention effi- ciency (PRE) of bivalve larvae varies among species (Riisgård 1980, 1988, Sprung 1984a, Baldwin 1995, Riisgård et al. 2000), and thus it is necessary to determine the size range of the potential larval diet (i.e. the PRE) in order to assess larval food abundance in nature.

The asari clam (Ruditapes philippinarum; also known as the Manila clam and short-necked clam) is indigenous to coasts of East Asia and Japan. The fishery production in Japan decreased from a maximal production of 140000 tonnes in 1985 to 35000 tonnes in 2005 (Ministry of Agriculture, Forestry and Fisheries, Japan 2007). Although the reason for the decrease is unknown, decreasing recruitment may be one cause (Ishii et al. 2001, Toba et al. 2007). Measures of larval food abundance in nature can be used to determine if larval growth is limited by food availability.

The PRE of asari clam larvae has not been determined, although the larvae can be grown in hatcheries on standard algal diets for bivalve larvae (e.g. Pavlova 
lutheri or Chaetoceros calcitrans) (Miyama \& Toba 1990, Yan et al. 2006). Information about the size of food particles in the natural larval diet may also improve larval rearing techniques in the hatchery. In this study, we investigated the clearance rate and PRE of asari clam larvae in natural seawater to better understand larval ingestion rates on natural food assemblages.

\section{MATERIALS AND METHODS}

PREs of asari clam larvae were examined in 4 separate experimental trials. Larval stage varied between trials; umbo stage to full-grown larvae were used. The clam larvae for the experiments were spawned and grown in our laboratory on standard algal diets (Pavlova lutheri, Chaetoceros calcitrans, or Chaetoceros gracilis). Natural seawater was collected for the experiments at a depth of $\sim 2$ to $5 \mathrm{~m}$ from the floating dock in front of our laboratory (water depth approximately $10 \mathrm{~m}$ ) during mid- to high tide using a Niskin water sampler. This area is a natural habitat for the asari clam. Collected seawater was filtered through a $20 \mu \mathrm{m}$ mesh screen and then poured into six $500 \mathrm{ml}$ plastic bottles. Equal volumes of a uniform suspension of clam larvae were added to 3 of the bottles and the remaining 3 bottles were treated as controls. Larval densities were high enough for significant particle reduction during the experimental period $(4 \mathrm{~h})$, but were not adjusted to the same density in every trial (range 4.9 to 28 larvae $\mathrm{ml}^{-1}$ ). An even distribution of particles and larvae was achieved in the experimental containers by continuous mixing, gentle bubbling in Trial 1 and with a plankton wheel (at $1 \mathrm{rpm}$ ) in the other 3 trials. Experiments were conducted at room temperature. Dates of each trial, larval size, larval density, temperature, salinity, and other experimental conditions are shown in Table 1.

Immediately after the addition of larvae and at the end of the $4 \mathrm{~h}$ experimental period, a sample of water ( $\sim 50 \mathrm{ml})$ was taken from each bottle and filtered through a $20 \mu \mathrm{m}$ mesh screen, then the particle concentration was determined using a Coulter Counter
Multisizer 3 fitted with a $30 \mu \mathrm{m}$ aperture tube (Beckman Coulter). The particle counter recorded the number and volume of particles in 0.25 to $0.3 \mathrm{ml}$ of sample. Particle concentration was determined for 32 size ranges between 0.8 and $18 \mu \mathrm{m}$. The values separating the 32 size ranges were defined by $\ln (0.8)+\mathrm{n} \times[\ln (18)$ $-\ln (0.8)] / 32$ for $n=0,1,2 \ldots 32$. Particle counting was repeated $6 \times$ for each sample, and the particle concentrations were averaged. To determine larval counts and shell lengths, duplicate or triplicate $10 \mathrm{ml}$ samples were taken from each experimental bottle at the end of the experiments and fixed with $3 \%$ neutral formalin or $1 \%$ glutaraldehyde. Larval numbers in the samples were counted using an inverted microscope. Larval shell length was determined from measurements of 50 larvae.

We calculated the rate of change in particle concentration $(k)$ for each of the 32 size ranges from the equation of Frost (1972):

$$
C_{2}=C_{1} \mathrm{e}^{k\left(t_{2}-t_{1}\right)}
$$

where $C_{1}$ and $C_{2}$ are particle concentrations $\left(\mu \mathrm{m}^{3} \mathrm{ml}^{-1}\right.$ ) in control bottles at times $t_{1}$ and $t_{2}$, respectively. For each larval bottle, the grazing coefficient $(g)$ was calculated from:

$$
C_{2}^{\prime}=C_{1}^{\prime} \mathrm{e}^{(\bar{k}-g)\left(t_{2}-t_{1}\right)}
$$

where $C_{1}^{\prime}$ and $C_{2}^{\prime}$ are particle concentrations in larval bottles at times $t_{1}$ and $t_{2}$, respectively, and $\bar{k}$ is the mean $k$ of the 3 control bottles. For each larval bottle, the average particle concentration, $\bar{C}$, during time interval $t_{2}-t_{1}$ was calculated as:

$$
\bar{C}=\frac{C_{2}^{\prime}-C_{1}^{\prime}}{\left(t_{2}-t_{1}\right)(\bar{k}-g)}
$$

For each larval bottle, the clearance rate $(\mathrm{CR}, \mu \mathrm{l}$ ind. ${ }^{-1} \mathrm{~h}^{-1}$ ) was calculated as:

$$
\mathrm{CR}=g / d
$$

where $d$ is the larval density. We used the mean larval count from the 3 experimental bottles as the value for $d$ because no statistically significant differences in larval counts were observed among the larval bottles in any

\begin{tabular}{|c|c|c|c|c|c|c|c|c|}
\hline Trial & $\begin{array}{l}\text { Date } \\
(2007)\end{array}$ & $\begin{array}{c}\text { Temperature } \\
\left({ }^{\circ} \mathrm{C}\right)\end{array}$ & $\begin{array}{l}\text { Salinity } \\
\text { (psu) }\end{array}$ & $\begin{array}{l}\text { Shell length } \\
\qquad(\mu \mathrm{m})\end{array}$ & Stage & $\begin{array}{l}\text { Larval density } \\
\quad \text { (ind. } \mathrm{ml}^{-1} \text { ) }\end{array}$ & Mixing method & $\begin{array}{c}\text { Spawn date } \\
(2007)\end{array}$ \\
\hline 1 & 19 Jun & $24.6 \pm 0.09$ & $31.7 \pm 0.05$ & $205.4 \pm 13.5$ & Full grown & $14.4 \pm 9.7(6)$ & Gentle bubbling & 5 Jun \\
\hline 2 & $13 \mathrm{Jul}$ & $24.5 \pm 0.12$ & $29.8 \pm 0.15$ & $141.1 \pm 11.8$ & Umbo & $28.0 \pm 8.5(9)$ & Plankton wheel & $6 \mathrm{Jul}$ \\
\hline 3 & $21 \mathrm{Aug}$ & $25.7 \pm 0.00$ & $31.8 \pm 0.06$ & $128.7 \pm 6.0$ & Umbo & $13.2 \pm 2.0$ & Plankton wheel & 15 Aug \\
\hline 4 & 30 Aug & $25.8 \pm 0.04$ & $30.7 \pm 0.00$ & $191.9 \pm 21.2$ & Full grown & $4.9 \pm 1.0(9)$ & Plankton wheel & 15 Aug \\
\hline
\end{tabular}
experiment.

Table 1. Experimental conditions for each trial. Data are mean \pm SD (n). Temperature and salinity were measured at the end of the experiments $(n=6)$ 
CRs over all particle size ranges were smoothed using the 'super smoother' function of the statistical software package $R$, which determines the best span for smoothing by using local cross-validation (Takezawa 2005, R Development Core Team 2008). The highest clearance rate (peak $\mathrm{CR}$ ) and the particle size of the peak CR were determined from the highest value of the smoothed lines. For each larval bottle, the ingestion rate $\left(\mathrm{IR}, \mu \mathrm{m}^{3}\right.$ ind..$^{-1} \mathrm{~h}^{-1}$ ) was calculated as:

$$
\mathrm{IR}=\bar{C} \times \mathrm{CR}
$$

The cumulative IR was also calculated by summing IR beginning at the $0.8 \mu \mathrm{m}$ size range. If the IR for a given size range was $<0$, that value was not included in the cumulative calculation.

\section{RESULTS}

Because we used natural seawater, the initial particle concentrations were different for each trial (Fig. 1).
In Trial 1, there was a peak in particle volume at the 10 to $13 \mu \mathrm{m}$ size, whereas in Trial 2, there were peaks at 4-6 and 10-13 $\mu \mathrm{m}$. In contrast, there were no clear peaks in particle size distributions in Trials 3 and 4 . Microscopic observation showed that the peaks in Trials 1 and 2 reflected the presence of several species of flagellates and diatoms, and were not due to a single dominant species.

There was a significant increase in particle concentration in the control bottles (Fig. $2 ; k>0, p=0.05$ ) for small particles $(<\sim 1.5 \mu \mathrm{m})$ in all trials. Significant decreases $(k<0, \mathrm{p}<0.05)$ were seen in approximately 3 to $6 \mu \mathrm{m}$ particles in Trials 1, 3, and 4 . Values for $k$ varied for the larger particles, especially in the $>13 \mu \mathrm{m}$ sizes in Trials 3 and 4 , showing a large rate of decrease $(k<-0.1)$.

We determined the $\mathrm{CR}$ for each size range in each trial (Fig. 3). Significant clearance was seen in the size ranges from $0.8-1$ to $8-9 \mu \mathrm{m}(\mathrm{p}<0.05)$. Overall, the CRs were highest for 1 to $3 \mu \mathrm{m}$ particles. We also measured negative CRs for 4 to $6 \mu \mathrm{m}$ particles in Trials 3 and 4 .

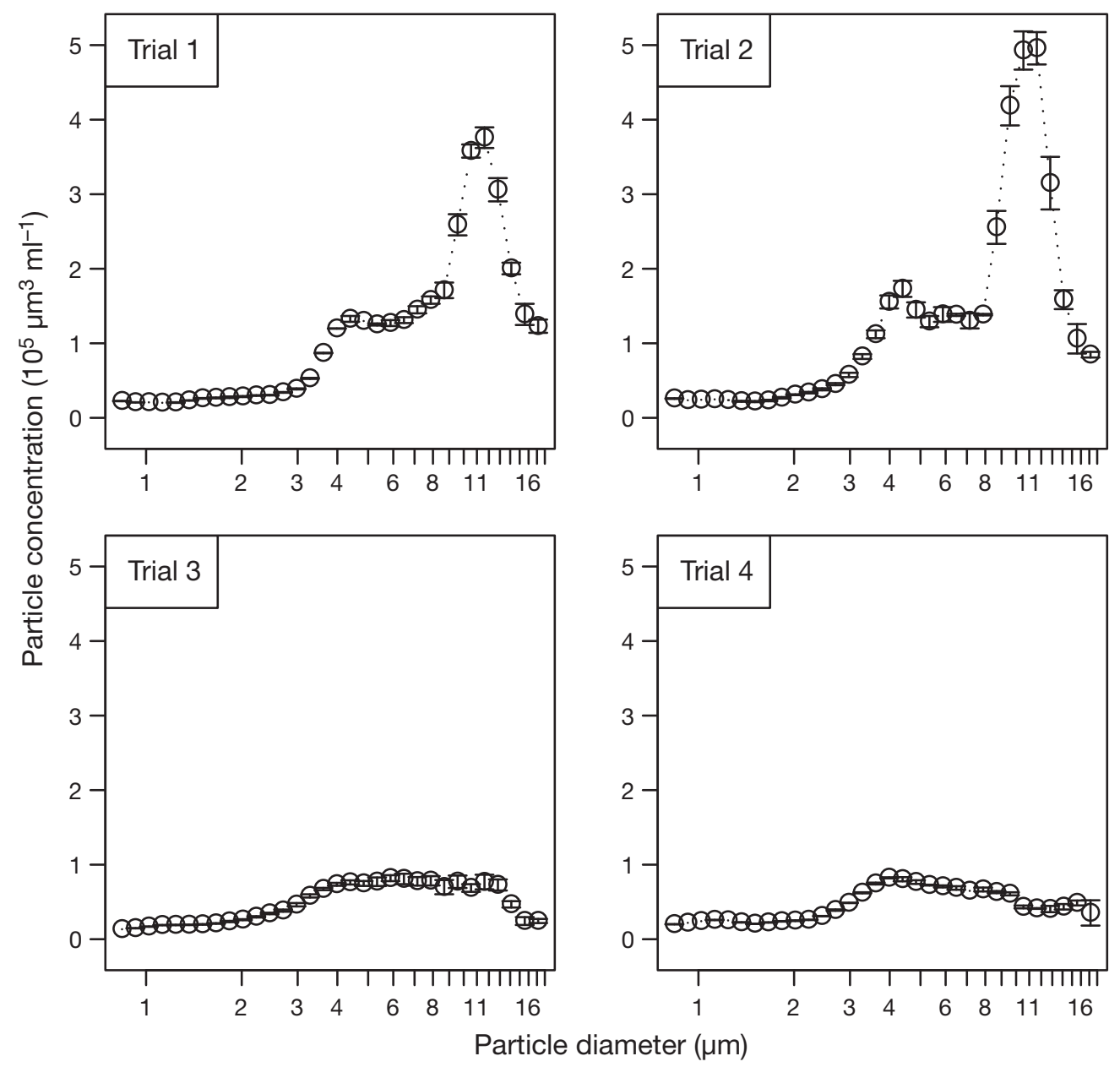

Fig. 1. Initial concentrations of particles in different size ranges for each trial in experimental bottles containing larvae (mean $\pm \mathrm{SD} ; \mathrm{n}=3$ for all trials) 


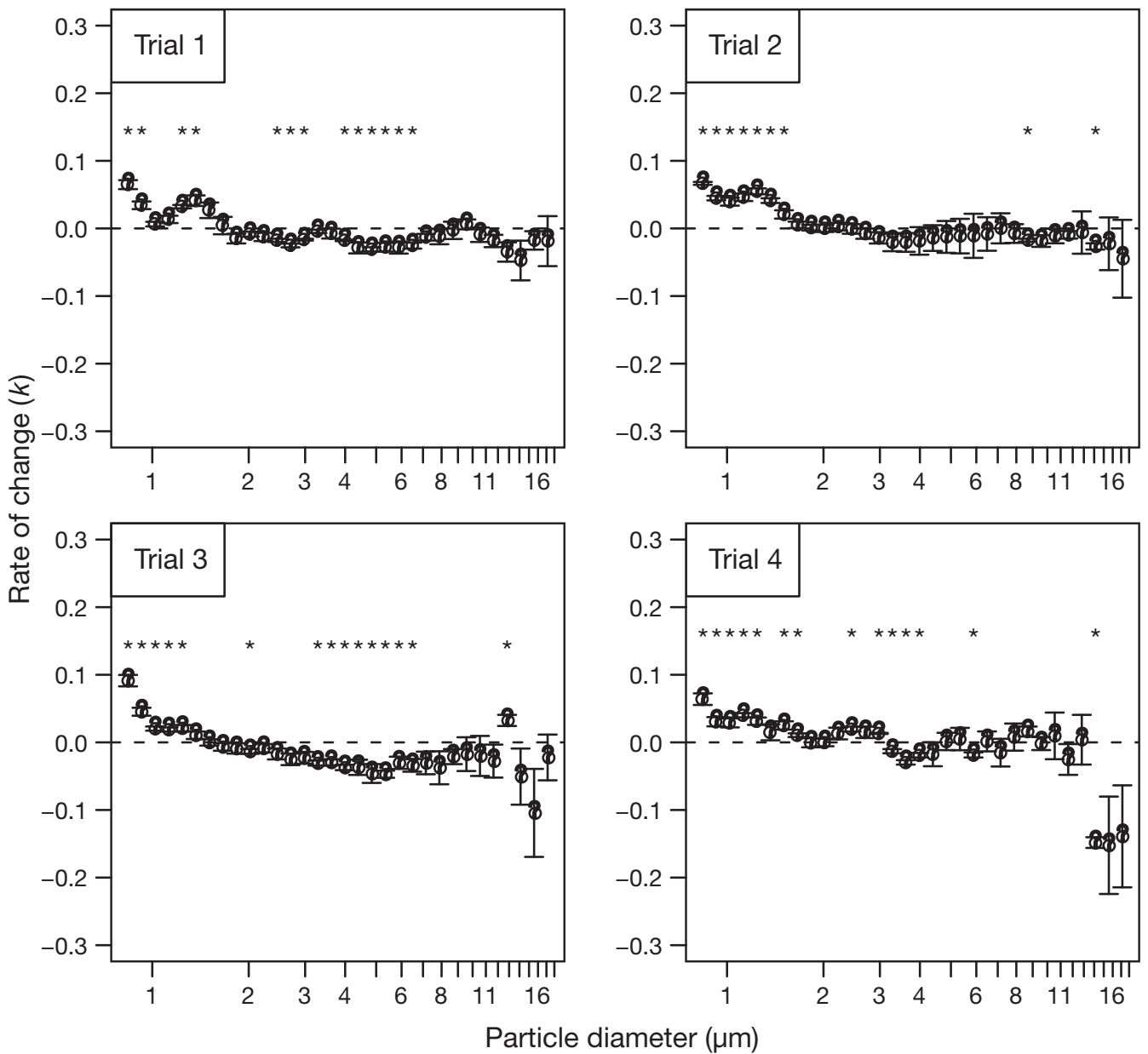

Fig. 2. Rate of change of particle concentrations in control bottles ( $k_{\text {; }}$ see Eq. 1 in text) for each trial (mean \pm SD of 3 bottles). ${ }^{*}$ Rates significantly different from $0(\mathrm{p}<0.05)$

The peak CR in the 4 trials ranged from 5.8 to $23.4 \mu \mathrm{l}$ ind. ${ }^{-1} \mathrm{~h}^{-1}$. Particle size of the peak CR ranged from 1.4 to $2.0 \mu \mathrm{m}$. Although particle size at peak CR seemed to increase with increasing larval shell length, the relationship was not statistically significant (Fig. 4; ANOVA, $\mathrm{p}=0.259$ ).

For each trial, the cumulative IR $\left(\mu \mathrm{m}^{3}\right.$ ind. $\left.^{-1} \mathrm{~h}^{-1}\right)$ increased with increasing particle size and reached a maximum at a particle size of $\sim 8$ to $10 \mu \mathrm{m}$. The maximum cumulative IR in the 4 trials ranged from $\sim 50 \times$ $10^{2}$ to $120 \times 10^{2} \mu^{3}$ ind..$^{-1} \mathrm{~h}^{-1}$ (Fig. 5)

\section{DISCUSSION}

In calculating CRs, we assumed that changes in the control bottles were applicable to the treatment bottles in the absence of larvae. It is important to examine the validity of this assumption. In the control bottles, we observed a significant increase in particles $<1.5 \mu \mathrm{m}$ in all trials (Fig. 2). These increases were probably caused by bacterial growth, as this rate of increase is within the range of growth rates of coastal bacteria (Yokokawa \& Nagata 2005). If the presence of larvae had any stimulative or inhibitory effect on bacterial growth, then the applicability of changes in control bottles becomes questionable. Significant decreases were seen in 3 to $6 \mu \mathrm{m}$ particles in the controls for Trials 1, 3, and 4. This might be from some grazing organisms that passed through the $20 \mu \mathrm{m}$ screen or from adhesion to the inner bottle surface. High rates of decrease were also seen for larger particles $(>\sim 13 \mu \mathrm{m})$ in Trials 3 and 4 . However, these decreases were not always statistically significant because of the large variance caused by the lower particle concentration in these size fractions in Trials 3 and 4 (Fig. 1). Because of this large variance, we suspect that these decreases were the same in the bottles containing larvae.

We observed similar patterns of PRE in the 4 trials. Significant CRs were seen in the $0.8-1$ to $8-9 \mu \mathrm{m}$ particle size fractions (Fig. 3). CRs were highest at the 1 to $3 \mu \mathrm{m}$ particle sizes. CRs for 4 to $6 \mu \mathrm{m}$ particles were 


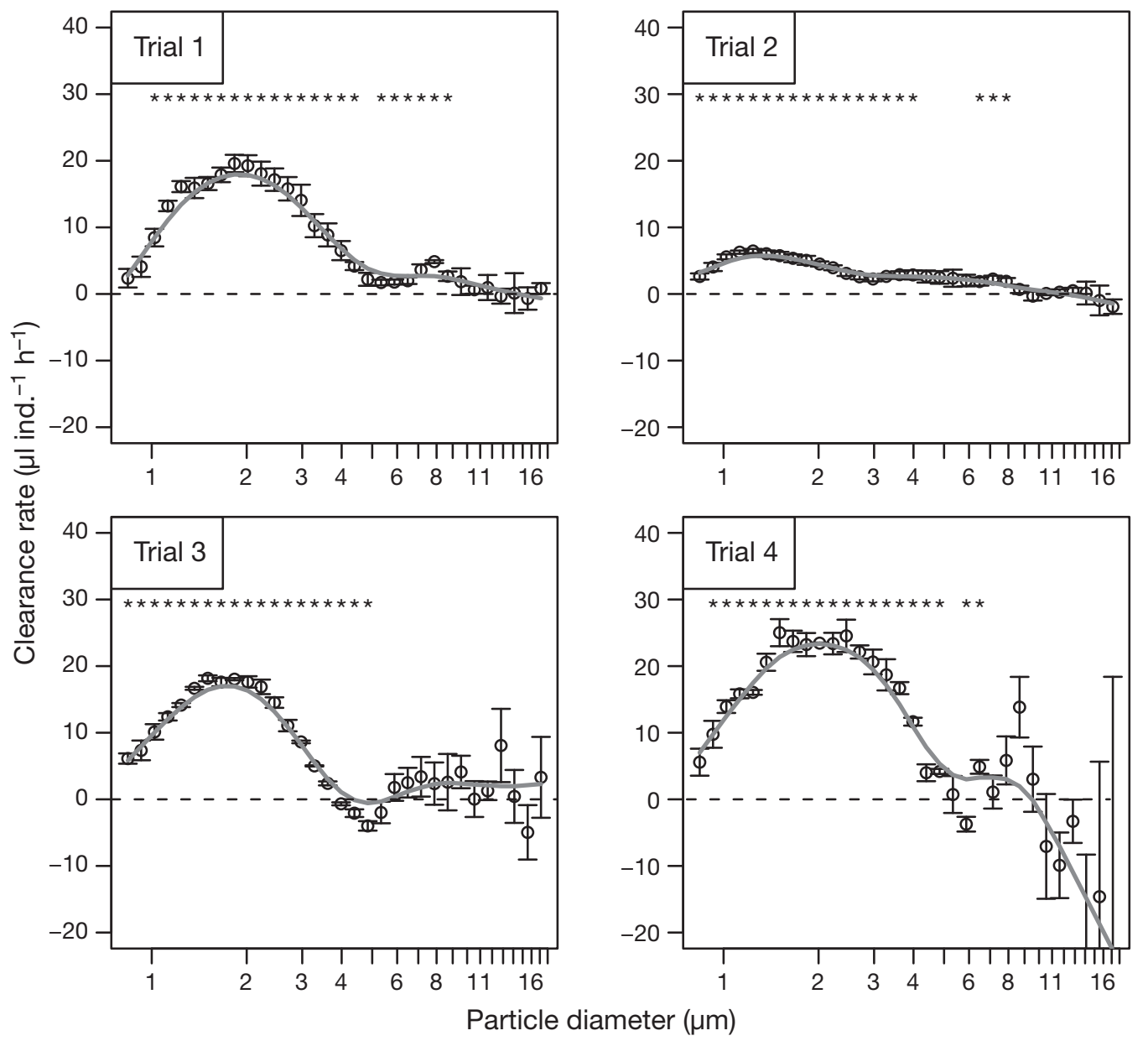

Fig. 3. Ruditapes philippinarum. Clearance rates (CR) by particle size for each trial. Error bars: SD of the 3 treatment bottles. ${ }^{*}$ Rates significantly different from $0(\mathrm{p}<0.05)$. (—) Clearance rate data after using a smoothing function (see text)

low in Trial 1, not significant in Trial 2, and negative in Trials 3 and 4 . The negative values might reflect fecal excretion, although effects of fecal production were not part of this study. The different mixing systems did not seem to affect the results, although the systems were not compared under identical conditions.

The peak CRs ranged from 5.8 to $23.4 \mu \mathrm{l}$ ind. ${ }^{-1} \mathrm{~h}^{-1}$ (Fig. 3). Differences in larval size and density among the 4 trials would explain this. CRs of Mytilus edulis larvae range from 19 to $37 \mu \mathrm{l}$ ind.$^{-1} \mathrm{~h}^{-1}$ for 156 to $195 \mu \mathrm{m}$ larvae at $18^{\circ} \mathrm{C}$ (Sprung 1984a). CRs in our study (5.8 to $23.4 \mu \mathrm{l}$ ind..$^{-1} \mathrm{~h}^{-1}$ ) were lower despite the higher experimental temperature $\left(24.5\right.$ to $\left.25.8^{\circ} \mathrm{C}\right)$. This might have resulted from the high larval densities used in this study. Larval CRs are reported to decrease with increasing larval density above 5 larvae $\mathrm{ml}^{-1}$ (Hansen 1991). The lowest peak CR in this study (Trial $2 ; 5.8 \mu$ ind $^{-1} \mathrm{~h}^{-1}$ ) coincided with the highest larval density (28 larvae $\mathrm{ml}^{-1}$ ) and smaller larval size (141.1 $\mu \mathrm{m})$.

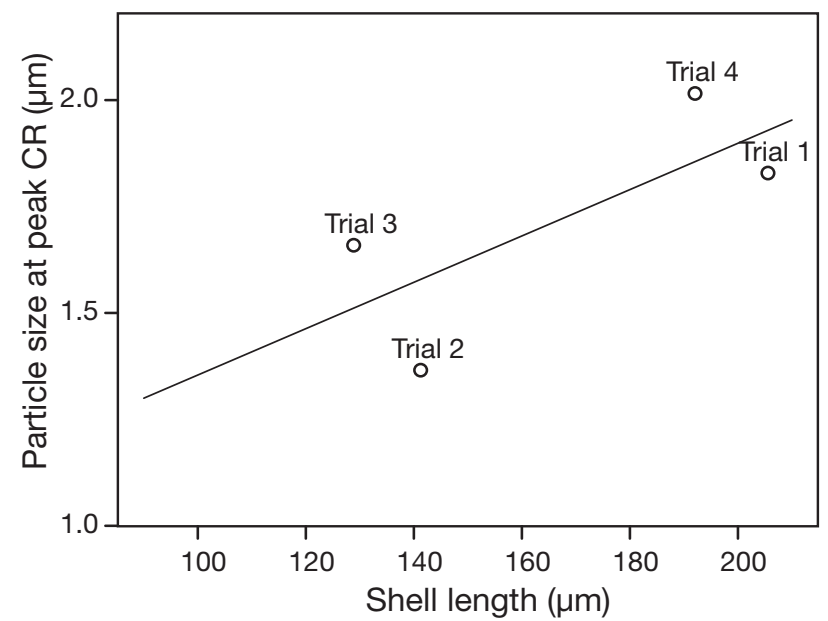

Fig. 4. Ruditapes philippinarum. Relationship between the particle size at peak clearance rate $(\mathrm{CR}, y)$ and shell length (SL) of larvae. A fit of the data to a linear model yielded $y=$ $0.81+0.00545 \times \mathrm{SL}$, although the relationship was not significant (ANOVA, $\mathrm{p}=0.259$ ) 


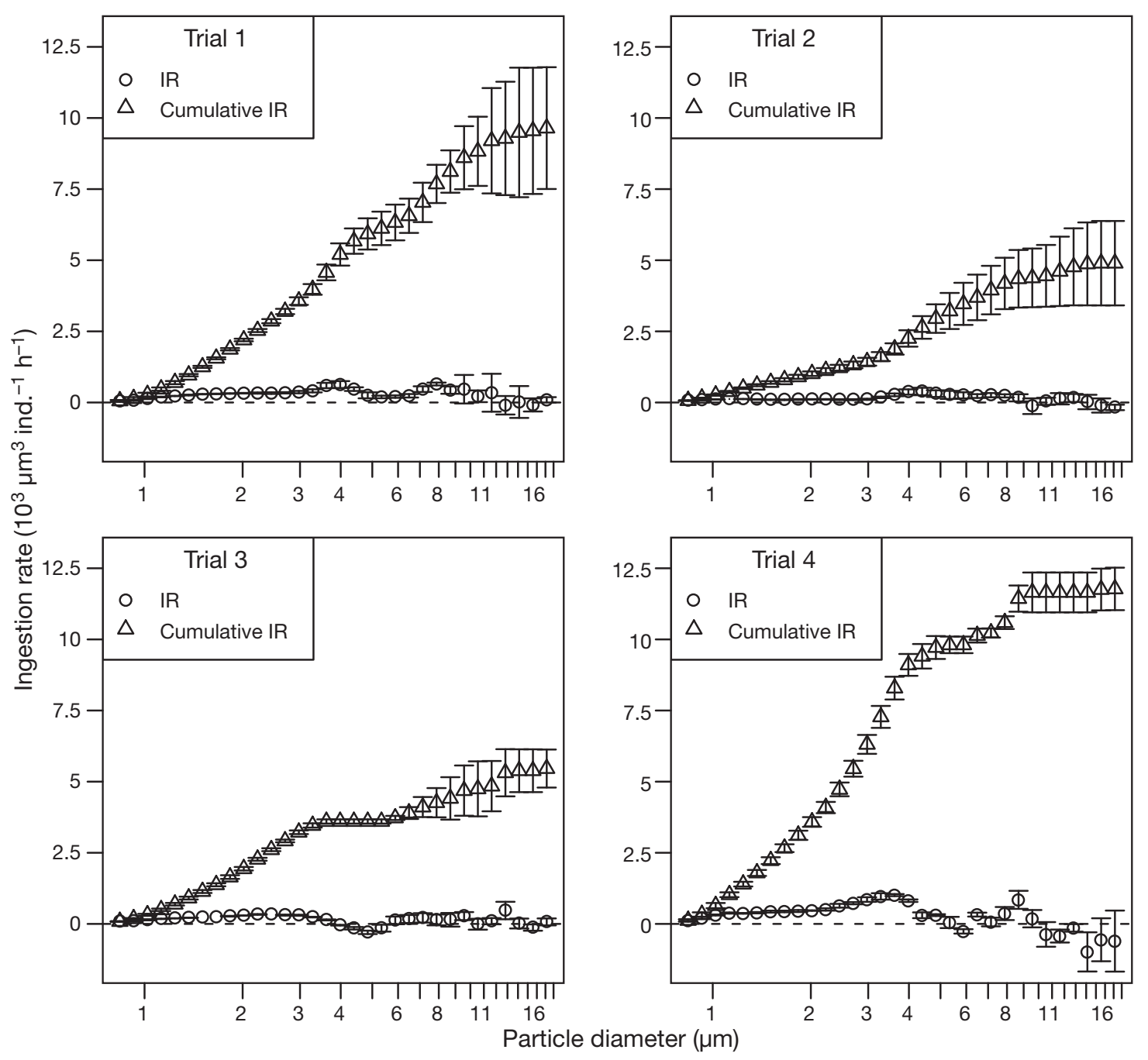

Fig. 5. Ruditapes philippinarum. Ingestion rate (IR) for each particle size range and cumulative IR. Error bars: SD of the 3 treatment bottles

Overall, larval densities in this study were much higher than in nature (Matsumura et al. 2001). The high larval density in Trial 2 might have reduced oxygen concentrations. At a larval respiration rate of $20 \mathrm{ng} \mathrm{O}_{2}$ ind. $^{-1}$ $\mathrm{h}^{-1}$ (Sprung 1984b and references therein), 28 larvae $\mathrm{ml}^{-1}$ could consume $2.2 \mu \mathrm{g} \mathrm{O}_{2} \mathrm{ml}^{-1}$ during the $4 \mathrm{~h}$ experiment, corresponding to $30 \%$ of the oxygen in saturated seawater $\left(7.5 \mathrm{mg} \mathrm{l}^{-1}\right)$. This reduction might have affected the larval CRs. It is also possible that the $4 \mathrm{~h}$ experimental period might have been too short to allow acclimation of larvae. Under our experimental conditions, the measured larval CRs might be lower than those in nature.

The particle size at the peak CR ranged from 1.4 to $2.0 \mu \mathrm{m}$ (Figs. $3 \& 4$ ) and did not increase significantly with increasing larval shell length. Larvae of Philine aperta retained a broader size range of particles, particularly larger ones, as larval shell length increased (Hansen 1991). This difference between species might have resulted from the difference in size ranges of the larvae studied: 149 to $392 \mu \mathrm{m}$ for P. aperta (Hansen 1991) and 128.7 to $205.4 \mu \mathrm{m}$ for Ruditapes philippinarum (this study).

PREs of asari clam larvae were similar to those of Mytilus edulis larvae (Riisgård 1980). M. edulis larvae at 5 and $13 \mathrm{~d}$ cleared 2.5 to $3.5 \mu \mathrm{m}$ particles at the highest rate, and particles $<1$ or $>8-9 \mu \mathrm{m}$ were not consumed. However, the particle sizes with highest CRs in this study were slightly smaller compared with those of other bivalve species: 2.5 to $3.5 \mu \mathrm{m}$ in $M$. edulis, $4 \mu \mathrm{m}$ in Mercenaria mercenaria, and 2 to $4 \mu \mathrm{m}$ in Crassostrea virginica (Riisgård 1980, Sprung 1984a, Riisgård 1988, Baldwin 1995, Riisgård et al. 2000). The standard algal diets used in the hatchery, including species such as Pavlova lutheri or Chaetoceros calcitrans (4 to $5 \mu \mathrm{m})$, might not be of the optimum size for asari clam larvae. 
The cumulative IR in this study ranged from $\sim 50 \times$ $10^{2}$ to $100 \times 10^{2} \mu \mathrm{m}^{3}$ ind. $^{-1} \mathrm{~h}^{-1}$ (Fig. 5). These values correspond to $100-200$ cells ind.$^{-1} \mathrm{~h}^{-1}$, assuming the cell volume of an algal diet species (such as Pavlova lutheri) to be $50 \mathrm{\mu m}^{3} \mathrm{cell}^{-1}$ ( 4.6 $\mu \mathrm{m}$ in diameter). These values are well below the levels of food supplied in hatcheries (5000 to 15000 cells ind. ${ }^{-1} \mathrm{~d}^{-1} ; \sim 200$ to 600 cells ind.$^{-1} \mathrm{~h}^{-1}$ ) for 120 to $200 \mu \mathrm{m}$ larvae (Chiba Prefectural Fisheries Research Center 2004). Because the CRs we determined might be underestimates, the ingestion rates of Ruditapes philippinarum under the same food concentrations in nature might be higher than indicated in this study. However, our results suggest that the food supply in the natural seawater used in this study was not concentrated enough for maximal growth of the larvae. Further studies are required to determine variations in larval food abundance and larval ingestion in nature.

Acknowledgements. We thank S. Kamimura and Y. Tomaru (National Research Institute of Fisheries and Environment of Inland Sea) for their helpful advice.

\section{LITERATURE CITED}

Baldwin BS (1995) Selective particle ingestion by oyster larvae (Crassostrea virginica) feeding on natural seston and cultured algae. Mar Biol 123:95-107

Bos OG, Hendriks IE, Strasser M, Dolmer P, Kamermans P (2006) Estimation of food limitation of bivalve larvae in coastal waters of northwestern Europe. J Sea Res 55:191-206

Bricelj VM, MacQuarrie SP (2007) Effects of brown tide (Aureococcus anophagefferens) on hard clam Mercenaria mercenaria larvae and implications for benthic recruitment. Mar Ecol Prog Ser 331:147-159

Chiba Prefectural Fisheries Research Center (2004) Basis of the practical techniques in the hatchery production of asari clam: experience of Futtsu laboratory. In: Chiba Prefectural Fishery Research Center (ed) Progress of Chiba Prefectural Fisheries Resarch Center IV. Chiba Prefectural Fishery Research Center, Chiba

Chícharo L, Chícharo MA (2001) Effects of environmental conditions on planktonic abundances, benthic recruitment and growth rates of the bivalve mollusc Ruditapes decussatus in a Portuguese coastal lagoon. Fish Res 53:235-250

Frost BW (1972) Effects of size and concentration of food particles on the feeding behavior of the marine planktonic copepod Calanus pacificus. Limnol Oceanogr 17:805-814

García-Esquivel Z, Bricelj VM, Gonzalez-Gomez MA (2001) Physiological basis for energy demands and early postlarval mortality in Pacific oyster, Crassostrea gigas. J Exp Mar Biol Ecol 263:77-103

> Hansen B (1991) Feeding behaviour in larvae of the opisthobranch Philine aperta. II. Food size spectra and particle selectivity in relation to larval behaviour and morphology of the velar structures. Mar Biol 111:263-270

Ishii R, Sekiguchi H, Nakahara Y, Jinnai Y (2001) Larval recruitment of the Manila clam Ruditapes philippinarum in Ariake Sound, southern Japan. Fish Sci 67:579-591

Laing I (1995) Effect of food supply on oyster spatfall. Aquaculture 131:315-324
Matsumura T, Okamoto S, Kuroda N, Hamaguchi M (2001) Temporal and spatial distributions of planktonic larvae of the clam Ruditapes philippinarum in Mikawa Bay: application of an immunofluorescence identification method. Jpn J Benthol 56:1-8 (in Japanese with English abstract)

Ministry of Agriculture, Forestry and Fisheries, Japan (2007) Annual report of statistics on fisheries and aquaculture production in 2005. Nourin Toukei Kyoukai, Tokyo (in Japanese)

Miyama Y, Toba M (1990) Studies on the seedling production of short-necked clam Ruditapes philippinarum Adams \& Reeve. III. Food value of 8 microalgae for the larva of asari clam, Ruditapes philippinarum Adams \& Reeve. Bull Chiba Pref Fish Exp Stn 48:93-96 (in Japanese with English abstract)

Ólafsson EB, Peterson CH, Ambrose WG (1994) Does recruitment limitation structure populations and communities of macro-invertebrates in marine soft sediments? - the relative significance of pre- and post-settlement processes. Oceanogr Mar Biol Annu Rev 32:65-109

Przeslawski R, Bourdeau PE, Doall MH, Pan J, Perino L, Padilla DK (2008) The effects of a harmful alga on bivalve larval lipid stores. Harmful Algae 7:802-807

R Development Core Team (2008) R: a language and environment for statistical computing. R Foundation for Statistical Computing, Vienna

Raby D, Mingelbier M, Dodson JJ, Klein B, Lagadeuc Y, Legendre L (1997) Food-particle size and selection by bivalve larvae in a temperate embayment. Mar Biol 127: $665-672$

Riisgård HU (1980) Rates of water processing, oxygen consumption and efficiency of particle retention in veligers and young post-metamorphic Mytilus edulis. Ophelia 19:37-47

Riisgård HU (1988) Feeding rates in hard clam (Mercenaria mercenaria) veliger larvae as a function of algal (Isocrysis galbana) concentration. J Shellfish Res 7:377-380

Riisgård HU, Nielsen C, Larsen PS (2000) Downstream collecting in ciliary suspension feeders: the catch-up principle. Mar Ecol Prog Ser 207:33-51

Sommer F, Stibor H, Sommer U, Velimirov B (2000) Grazing by mesozooplankton from Kiel Bight, Baltic Sea, on different sized algae and natural seston size fractions. Mar Ecol Prog Ser 199:43-53

Sprung M (1984a) Physiological energetics of mussel larvae (Mytilus edulis). II. Food uptake. Mar Ecol Prog Ser 17: 295-305

> Sprung M (1984b) Physiological energetics of mussel larvae (Mytilus edulis). III. Respiration. Mar Ecol Prog Ser 18: $171-178$

Takezawa K (2005) Introduction to nonparametric regression (Japanese edn). Yoshioka publishers, Kyoto

Thorson G (1950) Reproductive and larval ecology of marine bottom invertebrates. Biol Rev Camb Philos Soc 25:1-45

Toba M, Yamakawa H, Kobayashi Y, Sugiura Y, Honma K, Yamada H (2007) Observations on the maintenance mechanism of metapopulations, with special reference to the early reproductive process of the Manila clam Ruditapes philippinarum (Adams \& Reeve) in Tokyo Bay. J Shellfish Res 26:121-130

Yan X, Zhang G, Yang F (2006) Effects of diet, stocking density, and environmental factors on growth, survival, and metamorphosis of asari clam Ruditapes philippinarum larvae. Aquaculture 253:350-358

Yokokawa T, Nagata T (2005) Growth and grazing mortality rates of phylogenetic groups of bacterioplankton in coastal marine environments. Appl Environ Microbiol 71: 6799-6807 